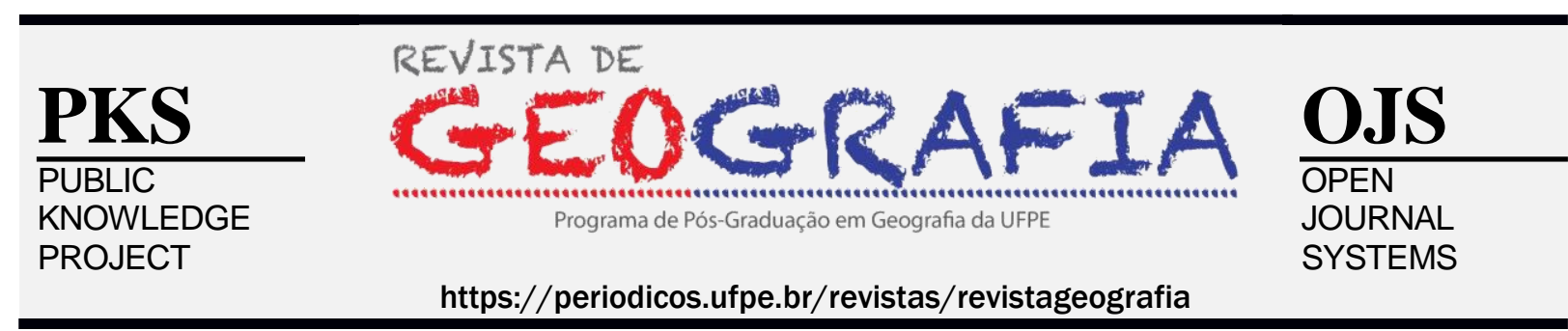

\title{
ENSINO DE GEOGRAFIA EM ESCOLAS INDÍGENAS DE MATO GROSSO DO SUL: LIMITES E DESAFIOS PARA A EDUCAÇÃO INTERCULTURAL
}

\author{
Solange Rodrigues da Silva ${ }^{1}$, Flaviana Gasparotti Nunes ${ }^{2}$ \\ ${ }^{1}$ Docente do Curso de Licenciatura Intercultural Indígena da Universidade Federal do Amapá-Campus \\ Binacional de Oiapoque.E-mail: so_ufms@hotmail.com \\ ${ }^{2}$ Docente do Curso do Programa de Pós-Graduação em Geografia da Universidade Federal da Grande \\ Dourados.E-mail: flaviananunes@ufgd.edu.br
}

Artigo recebido em 10/10/17 e aceito em 13/04/19

\begin{abstract}
RESUMO
Neste texto, apresentaremos parte das análises e reflexões desenvolvidas no âmbito de uma pesquisasobre o ensino de Geografia em escolas indígenas de Mato Grosso do Sul ${ }^{1}$, especificamente nos municípios de Caarapó, Dourados e Amambai. A partir de entrevistas realizadas com professores de Geografia atuantes em escolas indígenas desses municípios, realizamos análise das contribuições dessa disciplina para a educação intercultural. Além disso, refletimos sobre as concepções dos docentes entrevistados com os objetivos propostos para a Geografia nos projetos pedagógicos das escolas a fim de identificar convergências ou divergências. Concluímos que a complexidade presente nos contextos educacionais das escolas indígenas, marcada pela tensão entre o fazer diferente e a colonialidade do saber se expressa nas concepções dos docentes, assim como nos projetos pedagógicos das escolas.
\end{abstract}

Palavras-chave: ensino de geografia, educação escolar indígena, interculturalidade

\section{GEOGRAPHY TEACHING IN MATO GROSSO DO SUL INDIGENOUS SCHOOLS: LIMITS AND CHALLENGES OF AN INTERCULTURAL EDUCATION}

\begin{abstract}
In this text I will present some results that have been developed in my Doctor degree research, related with geography teaching in Mato Grosso do Sul indigenous schools, in the cities of Caarapó, Dourados and Amambai. Based on interviews conducted with Geography teachers working in indigenous schools in these cities, we intend to problematize the contributions that this school subject brought to intercultural education. Besides, we compare the conceptions of teachers interviewed with the main objectives proposed for the subject of Geography in pedagogical projects in order to identify convergences or divergences. We conclude that the complexity that this context presents is marked by tension between doing things differently and the coloniality of knowledge. They are expressed through teachers' conceptions as well as in the school pedagogical project.
\end{abstract}

Keywords: geography teaching, indigenous school education, interculturality

\footnotetext{
${ }^{1}$ A pesquisa em questão intitula-se “A Geografia na educação escolar indígena: reflexões a partir de Mato Grosso do Sul" foi financiada pelo CNPq (Edital 14/2012 - Universal)" e coordenada pela segunda autora do presente texto. Entre as produções resultantes desta pesquisa, está a tese de doutorado da primeira autora deste artigo na qual estão presentes parte das discussões aqui desenvolvidas.
} 


\section{INTRODUÇÃO}

Partimos da premissa que a educação intercultural, por não ser uma disciplina do currículo escolar, coloca-se como uma modalidade de pensar e produzir os diálogos entre as diferentes culturas existentes, reconhecendo não somente a diversidade, mas o valor de cada conhecimento e saber existente. Como enfatizam Souza e Fleuri, (2003, p. 73):

A educação intercultural, não sendo uma disciplina, coloca-se como outra modalidade de pensar, propor, produzir e dialogar com as relações de aprendizagem, contrapondo-se àquela tradicionalmente polarizada, homogeneizante e universalizante. A educação intercultural ultrapassa a perspectiva multicultural, à medida que não só reconhece o valor intrínseco de cada cultura e defende o respeito recíproco entre os diferentes grupos identitários, mas também propõe a construção de relações recíprocas entre esses grupos.

Tendo em vista que historicamente os povos indígenas sofreram influências das práticas coloniais instauradas desde a chegada do "colonizador", mas que persistem e estão enraizadas em nossa sociedade alicerçada na desqualificação de saberes outros, entendemos que a interculturalidade se coloca como elemento primordial na desconstrução do saber colonial/ocidental ainda presente nos contextos educacionais, inclusive nas escolas indígenas.

Para Lander (2005, p.13) o conhecimento ocidental é uma construção eurocêntrica, que impõe sua especificidade cultural como padrão de referência superior, e por conseguinte, "pensa e organiza a totalidade do tempo e do espaço para toda a humanidade do ponto de vista de sua própria experiência”.

Este metarrelato da modernidade é um dispositivo de conhecimento colonial e imperial em que se articula essa totalidade de povos, tempo e espaço como parte da organização colonial/imperial do mundo. Uma forma de organização e de ser da sociedade transforma-se mediante este dispositivo colonizador do conhecimento na forma normal do ser humano e da sociedade. As outras formas de ser, as outras formas de organização da sociedade, as outras formas de conhecimento, são transformadas não só em diferentes, mas em carentes, arcaicas, primitivas, tradicionais, pré-modernas LANDER (2005, p.13).

Este pensamento colonial ainda se faz presente no dia-a-dia das escolas indígenas, acarretando uma série de tensões e conflitos entre os conhecimentos tradicionais e a educação escolar indígena - construída com objetivos de transmitir conhecimentos, a partir de preceitos e condições que estão longe de serem em prol do bem comum, mas que foram consolidadas com base na visão ocidental na qual perpetuam relações de poder e exclusão. (FERREIRA, 2001) 
De acordo com o professor César Benites², “a desconstrução da educação imposta desde o período colonial é o principal obstáculo a ser superado atualmente no interior das escolas indígenas":

Hoje nós estamos lutando para que a alfabetização não seja um processo de aprisionamento imposto pelo colonizador. Temos muitas conquistas, mas, romper com o $\mathrm{BA}, \mathrm{BE}, \mathrm{BI}, \mathrm{BO}, \mathrm{BU}$, não é um processo fácil não. É só você observar as paredes das salas de aula da maioria das escolas indígenas de Dourados...Mesmo com todos os debates que temos participado, com todos os encontros de formação, que são discutidos, debatidos a importância da língua, da alfabetização na língua, ainda prevalece nas paredes da sala de aula o Alfabeto e os números do colonizador. (Professor Cesar Benites, em entrevista pessoal no dia 24/11/2015)

Para o professor Neimar Machado de Sousa ${ }^{3}$, o colonialismo existente em nosso país, que trabalha dia-a-dia no convencimento de que o saber do "outro" é mais importante, ainda se faz presente nas salas de aula das escolas indígenas. O convencimento de que nós "não somos", nós "não temos", nós "não pensamos", ou seja, o pensar colonial, ainda permanece em grande parte das práticas pedagógicas desenvolvidas nas escolas indígenas, inclusive por parte dos professores indígenas.

Nesse sentido, corroboramos com a análise de Skliar (2003) de que o aparato de poder colonial, seu saber, sua ciência, sua verdade, expresso principalmente por meio da produção de conhecimento pertencente originalmente ao colonizador, acaba mesmo de maneira lenta se transplantando para o colonizado.

Com base nesses fatos, buscaremos realizar uma breve caracterização das escolas indígenas dos municípios de Dourados, Amambai e Caarapó em Mato Grosso do Sul, no intuito de compreendermos como a interculturalidade comparece no dia-a-dia dessas escolas e quais e/ou limites existentes na luta por uma educação de fato descolonial.

\section{CARACTERIZAÇÃO DAS ESCOLAS PESQUISADAS}

O estado de Mato Grosso do Sul se destaca no cenário nacional por possuir a segunda maior população indígena do país. Nas 77 aldeias existentes no estado vivem aproximadamente 73.295 indígenas das etnias Atikum, Guarani Kaiowá, Guarani Nandeva,

\footnotetext{
${ }^{2}$ Professor Cesar Benites, em entrevista pessoal no dia 24/11/2015.

${ }^{3}$ Reflexão realizada durante a primeira formação da Ação Saberes Indígenas na Escola para os professores dos Anos Finais do Ensino Fundamental realizada no dia 16/09/2016, na E.M.I Araporã, localizada na Aldeia Jaguapiru - RID. 
Guató, Kadiwéu, Kiniquinau, Ofaié e Terena ${ }^{4}$ e, por conseguinte, existem várias escolas indígenas.

Devido à complexidade desta realidade, principalmente no que se refere ao número de etnias existentes nas 77 aldeias com suas características e especificidades, delimitamos como recorte de estudo as escolas indígenas dos municípios de Dourados, Caarapó e Amambai. A definição desse recorte se deu pela significativa presença de indígenas (figura 1) e consequentemente de escolas indígenas para atender estas populações.

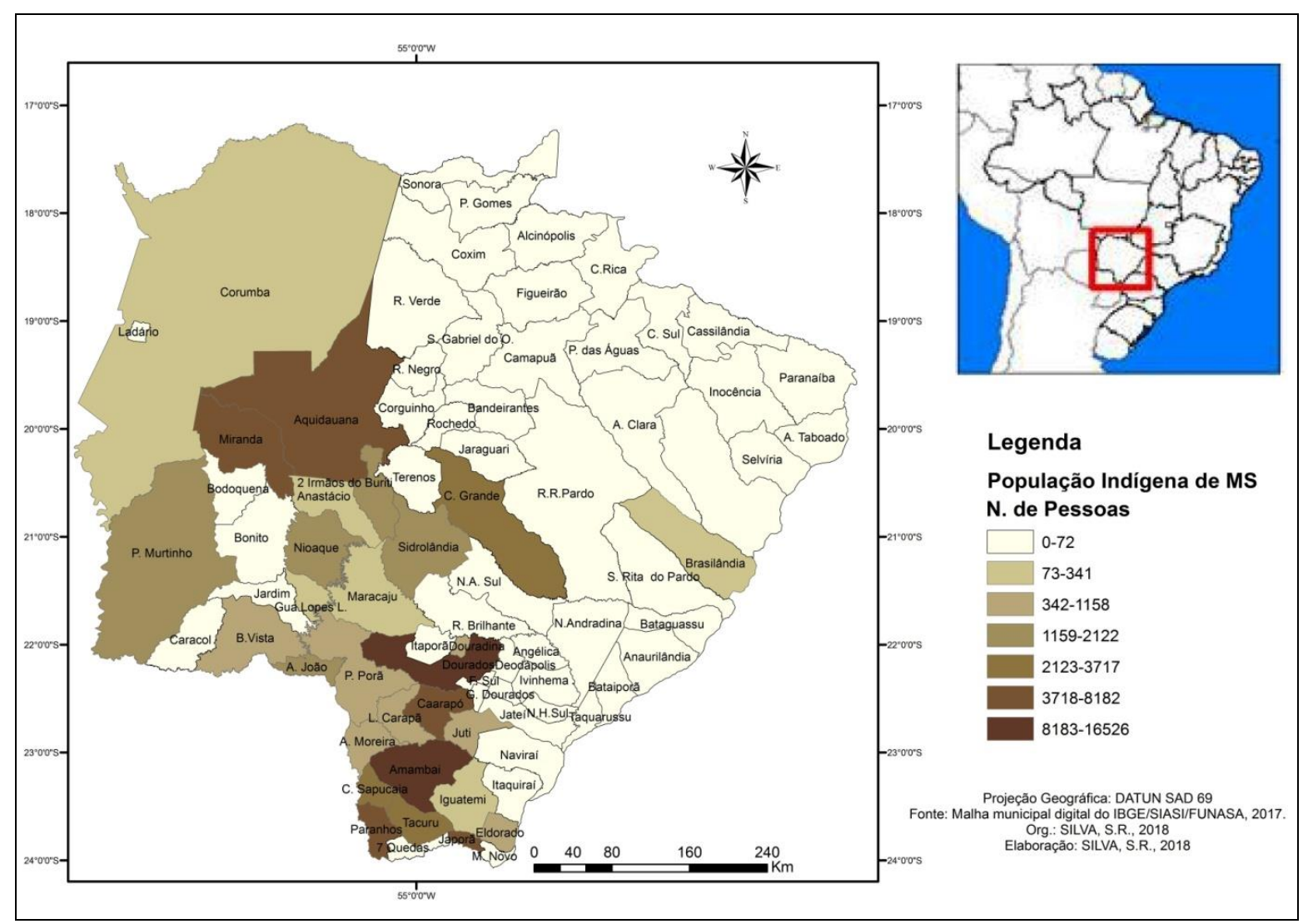

Figura1: Distribuição da população indígena por município em Mato Grosso do Sul Elaboração: Silva, S.R. (2018)

Iniciamos nossa análise com as escolas indígenas no município de Dourados localizado na porção Sul do estado de Mato Grosso do Sul (figura 1), que possui em seus limites duas áreas indígenas: Terra Indígena Panambizinho e Terra Indígena Francisco Horta Barbosa, mais conhecida como Reserva Indígena de Dourados (RID).

Criada no ano de 1917 por meio do Decreto n ${ }^{\circ} 401$ de 03/09/1917, a RID recebeu o título definitivo somente no ano de 1965. Atualmente possui uma área de 3.539 hectares e está localizada a Norte da cidade de Dourados, tendo seus limites territoriais junto ao perímetro

\footnotetext{
${ }^{4}$ MATO GROSSO DO SUL. Relatório de dados populacionais do Sistema de Atenção a Saúde Indígena (SIASI). Disponível em: http://dw.saude.gov.br/ Acesso em: 30/05/2015. 
urbano deste município e, ao Sul da cidade de Itaporã, a uma distância de $15 \mathrm{~km}$ desta localidade.

A Reserva é composta por 2 aldeias indígenas (Bororó e Jaguapiru) onde habitam aproximadamente 12.880 indígenas $^{5}$ de três etnias: Guarani Nandeva, Guarani Kaiowá e Terena, além dos não indígenas que ali são integrados, principalmente pela união conjugal com os indígenas, configurando como proposto por Pereira (2004), um "sistema multiétnico" de relações.

$\mathrm{Na}$ RID existem atualmente seis escolas municipais indígenas para a Educação Básica, sendo que destas três localizadas na Aldeia Bororó: E.M.I Agustinho, E.M.I Araporã, E.M.I Roque Isnard; três localizadas na aldeia Jaguapiru: E.M.I Ramão Martins, E.M.I Tengatuí Marangatu Polo; além da escola Francisco Meireles, que, apesar de não ser escola indígena, atende um número expressivo de alunos indígenas. Para atender os alunos do Ensino Médio, o município conta com a escola estadual de ensino médio intercultural GUATEKA também localizada na aldeia Jaguapiru.

De acordo com dados obtidos junto a Coordenadoria Especial de Assuntos Indígenas (CEAID), no ano de 2015 estavam regularmente matriculados nas escolas do município 4.133 alunos das etnias Guarani Kaiowá, Guarani Ñandeva e Terena. Delimitamos como recorte de pesquisa apenas as Escolas Municipais Indígenas Araporã, Tengatui Marangatu Polo, Agustinho, Ramão Martins e Guateka, localizadas na RID, que possuem professores de Geografia em seu quadro de profissionais. ${ }^{6}$

O município de Amambai localiza-se na porção meridional do Estado de Mato Grosso do Sul (figura 1) e possui em seus limites duas reservas indígenas ${ }^{7}$ : Reserva Indígena Amambai, situada na Rodovia MS 156 - Amambai/Ponta Porã a 6 quilômetros da cidade; a Reserva Indígena Limão Verde - situada na Rodovia MS 156 - Amambai/Tacuru, a 6 quilômetros da cidade.

O município possui duas escolas indígenas municipais: Escola Municipal Mbo’eroy Guarani Kaiowá e Escola Municipal Polo Indigena Tupã I'Nandeva e uma escola indígena

\footnotetext{
${ }^{5}$ MATO GROSSO DO SUL. Relatório de dados populacionais do Sistema de Atenção a Saúde Indígena (SIASI). Disponível em: http://dw.saude.gov.br/ Acesso em: 14/01/2017

${ }^{6}$ A escola Roque Isnard por atender somente as séries iniciais, não possui em seu quadro de funcionários professor de Geografia. Apesar de atender um número expressivo de alunos indígenas, a escola Francisco Meireles não possui tipologia de escola indígena e está localizada fora da área da Reserva.

${ }^{7} \mathrm{O}$ município de Amambai possui ainda em seus limites a Terra Indígena Jaguari, homologada pelo Decreto s/n - 22/05/1992, situada na Rodovia MS-289, na Rodovia Amambai/Juti, a 57 quilômetros da cidade de Amambai/MS. Porém, por não ser uma Reserva Indígena e não possuir professor de Geografia atuante em sua escola não optamos por não a contemplar nessa pesquisa. 
estadual para atender os alunos do Ensino Médio - Estadual Indígena Mbo'eroy Guarani Kaiowá.

A Escola Municipal Pólo Indígena MBO’eroy Guarani Kaiowá, situada na Aldeia Amambai, foi criada pela Lei Municipal $n^{\circ} 1.293$, de 14 de Novembro de 1990, atendendo a reivindicação da comunidade local e alterada pelas leis $\mathrm{n}^{\circ}$ 1.508/98 de 28/05/98, 1517/98 de

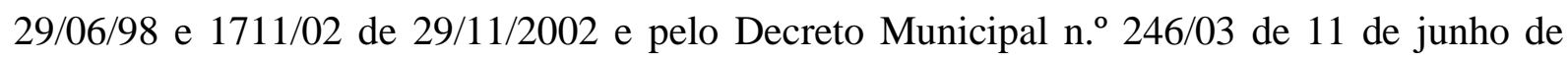
2003.

A escola atende desde a Educação Infantil (Pré II) até as séries finais do Ensino Fundamental e também a Educação de Jovens e Adultos (EJA): anos iniciais e finais. Segundo dados extraídos do censo escolar $/ 2015^{8}$, a escola tinha regularmente matriculados 1.389 alunos das etnias Guarani e Kaiowá. No ano de 2015, a escola contava com 62 professores em seu quadro docente, sendo que destes, um professor de Geografia concursado no município e cedido para atuar na escola indígena e um professor contratado.

A Escola Municipal Indígena Pólo Mbo Erenda Tupã I Nandeva (Pequeno Deus), situa-se na Aldeia Limão Verde. A escola funciona desde o ano de 1990 como extensão da escola da aldeia Amambai e como unidade escolar desde 2002. No ano de 2015 a escola possuía regularmente matriculados 419 alunos das etnias Guarani e Kaiowá.

Para atender os alunos do Ensino Médio o município conta, ainda, com a Escola Estadual Indígena Mbo'eroy Guarani Kaiowá, criada em 24/05/2005 pelo decreto nº 11.80 . Esta escola está localizada na Aldeia Amambai, Rodovia Amambai/Ponta Porã - km 05. A escola oferece Ensino Médio na modalidade regular e EJA (Educação de Jovens e Adultos), perfazendo no ano de 2015 um total de 313 alunos, com 17 professores, sendo destes 1 professor de Geografia.

O Município de Caarapó faz divisa ao Norte com o município de Dourados, ao Sul com Juti e Amambai, ao Leste com Fátima do Sul, Jatei e Vicentina e a Oeste com Laguna Carapã (figura 1). O município possui em seus limites a Reserva Indígena José Bonifácio, criada por meio Decreto Estadual $\mathrm{n}^{\circ}$. 684, de 20 de novembro de 1924, com uma área de 3.600 ha, sendo a terceira reserva Indígena demarcada no então estado de Mato Grosso.

A Reserva que também é conhecida como Reserva Indígena Te`yikue, e/ou Reserva indígena de Caarapó, está localizada a 19 quilômetros do perímetro urbano do município de Caarapó). Devido a pressões e invasões do entorno, a Reserva teve seu espaço territorial

\footnotetext{
${ }^{8}$ MATO GROSSO DO SUL. Secretaria de Estado de Educação. Dados Oficiais do Censo Escolar de 2015. Disponível em: www.sed.ms.gov.br/ Acesso em: 10/12/2016

$\begin{array}{lll}\text { Silva e Nunes, } 2019 & \text { ISSN 0104-5490 }\end{array}$
}


reduzido (BRAND, 1997), contando atualmente com 3.594 hectares, onde residem 4.661 indígenas das etnais Guarani Ñandeva e Guarani Kaiowá, oriundas de um extenso território que ultrapassa os limites do Brasil.

Existem no município de Caarapó duas escolas indígenas, ambas localizadas na Reserva Indígena Te`Yikue. A escola municipal - a Nãndejara-pólo, criada e sancionada através da Lei Municipal nº 666 de 10 de novembro de 2000 que possui três extensões: Escola Loide Bonfim Andrade, Escola Mbokaja e Escola Saverá; todas localizadas na aldeia Te'yikue. De acordo com dados fornecidos pela professora Anari Felipe Nantes, no ano de 2015 estavam regularmente matriculados 1.544 alunos das etnias Guarani Kaiowá e Guarani Ñandeva. A escola possui em seu quadro de docentes dois professores de Geografia, ambos não indígenas.

A Escola e suas Extensões atendem desde a Educação Infantil (pré-escola), anos iniciais do Ensino Fundamental ( $1^{\circ}$ ao $5^{\circ}$ ano) e anos finais do Ensino Fundamental $\left(6^{\circ}\right.$ ao $9^{\circ}$ ano). A metodologia trabalhada na escola é subsidiada a partir de temas geradores ${ }^{9}$, fundamentados pela perspectiva pedagógica de Paulo Freire, que para D`Angelis (2012), parece ser a mais adequada à construção de uma escola indígena. "Essa perspectiva aponta, necessariamente, para a construção da autonomia, como decorrência de um princípio políticopedagógico da proposta: educar não é transferir conhecimento, mas criar possibilidades para sua construção". (p.79)

Os temas geradores trabalhados na escola são definidos de acordo com a realidade e/ou necessidade da comunidade, escolhidos por um grupo formado pela Coordenação Pedagógica, Professores e Direção. No ano de 2015 a escola tinha regularmente matriculados 232 alunos das etnias Guarani e Kaiowá, sendo que destes, 102 eram alunos do Ensino Médio regular e 130 eram alunos da Educação de Jovens e Adultos (EJA) ${ }^{10}$.

Para atender os alunos de ensino médio o município possui a escola estadual indígena Yvy Poty, que iniciou as atividades no ano de 2006, por meio do Decreto $\mathrm{n}^{\mathrm{o}} 12035$ de 02 de fevereiro.

Esta escola foi criada por reivindicação da comunidade tendo em vista que os alunos que concluíam o ensino fundamental na Escola Municipal necessitavam se deslocar até a sede do município de Caarapó para dar continuidade a seus estudos, "mas acabavam desistindo por

\footnotetext{
${ }^{9}$ A ideia de trabalhar com os temas Geradores surgiu devido a assessoria do Programa Kaiowá e Guarani, sendo a formação continuada desenvolvida durante as horas de atividades, fundamental para a partilha das experiências, estudos e reflexão. (BENITES, 2014, p.84)

${ }^{10}$ MATO GROSSO DO SUL. Secretaria de Estado de Educação. Dados Oficiais do Censo Escolar de 2015. Disponível em: www.sed.ms.gov.br/ Acesso em: 10/12/2016

\begin{tabular}{lll}
\hline Silva e Nunes, 2019 & ISSN 0104-5490
\end{tabular}
} 
não se adaptarem ao sistema regular de ensino, ao preconceito, à discriminação e a um currículo escolar alheio ao seu contexto cultural e histórico”. (Yvy Poty, PPP, 2015, p.2)

Guardadas as particularidades de cada realidade pesquisada, as conquistas e a luta pela construção de uma educação intercultural/descolonial estão envoltas nas dubiedades que permeiam esse processo, uma vez que a luta entre o fazer diferente se choca cotidianamente com a colonialidade que persiste. A dubiedade existente entre a busca de como fazer diferente e o pensar ocidental que permanece em nosso país desde a chegada dos "colonizadores", e que vai subsidiar o modelo hegemônico de educação imposto pelo Estado brasileiro acaba por refletir diretamente nas práticas dos professores em sala de aula ${ }^{11}$.

Estas questões perpassam principalmente, pela necessidade de desconstrução do modelo de escola, fundamentada desde a sua criação por uma mentalidade colonialista e que consequentemente está enraizada nos pensamentos dos professores não indígenas, mas também dos professores indígenas, que, em grande parte, foram formados por este modelo de escola. Esta situação foi explicitamente evidenciada nas considerações do professor Eliel Benites (2014, p.127):

Mesmo com o grande esforço dos professores indígenas de fazer o "diferente" na sua prática pedagógica, eles ainda se movem dentro do sistema tradicional de educação colonizador e homogeneizador, a partir do qual foi construída a sua identidade. Para romper essas algemas procuramos, nos espaços alternativos do contexto escolar, fazer a educação com a metodologia kaiowá e guarani. Mas parece que a necessidade de responder às demandas externas - e não às internas - ainda orienta a prática da educação escolar.

No caso específico da disciplina de Geografia, acrescenta-se o fato de que a partir do $6^{\circ}$ ano do Ensino Fundamental, os professores que atuam nas escolas não são professores indígenas e, consequentemente, não falantes da língua guarani, o que acaba evidenciando a necessidade de práticas pedagógicas que valorizem o diálogo entre os conhecimentos geográficos e os elementos da vivência e da realidade dos alunos indígenas. Para isso é primordial a compreensão de que as práticas espaciais dos alunos são produtoras de geografias e consequentemente, “[...] os conteúdos geográficos, trabalhados em sala de aula deve ter significado para os alunos, devem servir para sua compreensão do mundo e seu lugar no mundo". (CAVALCANTI, 2012, p. 116)

\footnotetext{
${ }^{11}$ Cabe destacar que apesar dos limites encontrados para efetivação da educação escolar indígena específica, diferenciada e intercultural, encontramos professores que atuam nas escolas indígenas dos municípios pesquisados e buscam trabalhar a educação escolar indígena respeitando as especificidades das comunidades em que as escolas estão inseridas. Uma análise mais aprofundada das práticas desenvolvidas por estes professores será desenvolvida mais à frente neste artigo. 
Tendo como referência entrevistas realizadas com professores de Geografia atuantes nas escolas indígenas e a análise dos Projetos Político Pedagógicos das referidas escolas, a seguir, apresentamos elementos que nos permitam identificar as características da Geografia trabalhada nas escolas indígenas pesquisadas, bem como os desafios postos à construção da educação específica, diferenciada e intercultural.

\section{OS DESAFIOS DO ENSINO DE GEOGRAFIA NAS ESCOLAS INDÍGENAS DOS MUNICÍPIOS DE DOURADOS, CAARAPÓ E AMAMBAI (MS)}

Partimos do pressuposto que a Geografia "trata-se de um tipo de conhecimento e, portanto, de um conjunto de respostas que a sociedade constrói para compreender alguns dos aspectos de sua relação consigo e com o mundo" (SANTOS, 2007, p. 17). Para o professor Douglas Santos, assim como os demais componentes curriculares, o ensino de Geografia possui códigos e linguagem próprios e, portanto, se realiza enquanto um processo alfabetizador:

Observar paisagens ordená-las de forma a se tornarem territórios e vivenciálas de maneira a regionalizá-las, são operações que desenvolvemos desde a infância. Na escola aprenderemos como transformar todas essas experiências em mensagens faladas e escritas - além de dominarmos a habilidade de reconhecer as mensagens faladas e escritas por outros. (SANTOS, 2007, p. 17).

No contexto específico de escolas indígenas, esse exercício se dá no sentido de propor o diálogo entre os saberes e conhecimentos indígenas e os conhecimentos da sociedade não indígena, auxiliando os alunos na leitura de suas paisagens, territórios, regiões, lugares, espaços, mas também na leitura das paisagens, territórios regiões, espaços "outros", identificando como isso interfere na forma como as organizações sociais acontecem, bem como as implicações dessas organizações nas suas paisagens, territórios, regiões, lugares, espaços.

Com base em um questionário aplicado junto aos professores de Geografia atuantes nas escolas indígenas dos municípios de Dourados, Amambai, Caarapó e análise realizada aos PPPs das escolas indígenas pesquisadas, buscamos identificar como a Geografia trabalhada nessas escolas está contribuindo para uma educação intercultural e/ou quais limites e obstáculos colocados para formação de professores desta disciplina.

Para análise dos questionários nos reportamos a Cavalcanti (2012) que destaca que os estudos recentes sobre o ensino de Geografia sinalizam para a necessidade de se trabalhar com os conteúdos escolares sob uma perspectiva crítica, criativa, questionadora, em que os 
saberes científicos possam interagir e confrontar com outros saberes. Para a referida autora, os estudos recentes sobre o ensino de Geografia têm apontado para a necessidade dessa disciplina considerar os conhecimentos prévios dos alunos, e suas representações sobre os diferentes lugares existentes.

\begin{abstract}
Para a Geografia, alerta-se para a relevância dos conhecimentos cotidianos dos alunos, especialmente a respeito do lugar onde vivem e suas representações sobre os diferentes lugares do globo. $O$ professor deve captar os significados que os alunos dão aos conceitos científicos que são trabalhados no ensino. Para formar um pensamento espacial, é necessário que eles formem conceitos geográficos abrangentes, que são ferramentas fundamentais para compreender os diversos espaços, para localizar e analisar os significados dos lugares e sua relação com a vida cotidiana. (CAVALCANTI, 2010, p.7) (Grifos nossos)
\end{abstract}

Identificamos nas falas dos professores de Geografia atuantes nas escolas indígenas do município de Dourados, quando questionados sobre a contribuição desta disciplina para a educação intercultural, uma ênfase atribuída à necessidade desta disciplina considerar e/ou partir da realidade vivenciada pelos alunos e suas representações sobre diferentes lugares do globo. (Ver quadro 1)

Quadro 1: Entendimento dos professores de geografia atuantes nas escolas indígenas da RID sobre a contribuição a Geografia para educação intercultural

A Geografia contribui no sentido de possibilitar ao aluno compreender a sua realidade, a sua localização. Por exemplo, o porquê de ele viver naquele lugar, como se deu o processo de construção da Reserva, entender que as Reserva não é coisa de índio. Aí ele entende a realidade vivenciada hoje, a realidade do lugar onde vive, e a partir daí a realidade da cidade, do estado do país, mundo, e a relação desses lugares, espaços, territórios com o lugar onde eles vivem. (Professora de Geografia da Escola Municipal Indígena Araporã - Em entrevista pessoal no ano de 2015)

Está contribuindo com o valor da preservação do meio ambiente, o processo de transformação do espaço e a interação da sociedade no processo de globalização. (Professor de Geografia da escola Municipal Indígena Tengatuí Marangatu Polo; Escola Estadual Indígena de Ensino Médio Intercultural Guateka- Marçal de Souza. Em entrevista pessoal, no ano de 2015)
Ó que fazemos, quando organizamos nosso planejamento escolar, pensamos primeiro no particular o que temos na Aldeia, como vamos tratar esta questão com os alunos. Falamos sobre questões ambientais. Organizamos projetos, como: "Horta em ambiente escolar" "A importância da arborização da escola" o "Trânsito em nossa aldeia". Devemos sempre observar o olhar do aluno, como ele vê estas questões. Sempre que tratamos de uma questão mais geral procuramos mostrar a realidade da aldeia e o que pode ser feito. (Professora de Geografia da escola municipal Ramão Martins- Em entrevista Pessoal no ano de 2015)

Então, no começo do ano eu trabalhei com eles que toda a América Latina tinha a etnia Guarani, uma grande presença dos povos indígenas. Então, o idioma além do português e do espanhol é o guarani né, que predomina. Então além de toda a população indígena do nosso país, nos outros países também que fazem divisão. E aí a gente pode conhecer através dos mapas, toda as regiões né, Guarani. E a Geografia contribui assim, na localização, para que eles possam se identificar, nos outros países da América. (Professora de Geografia E. M.I. Agustinho. Em entrevista pessoal no ano de 2015)

Org.: Silva, S.R. 2017 
Essa situação/condição também se faz presente nos objetivos da Geografia propostos no interior dos Projetos Político Pedagógicos de parte das escolas indígenas do município de Dourados, como podemos verificar no quadro 2.

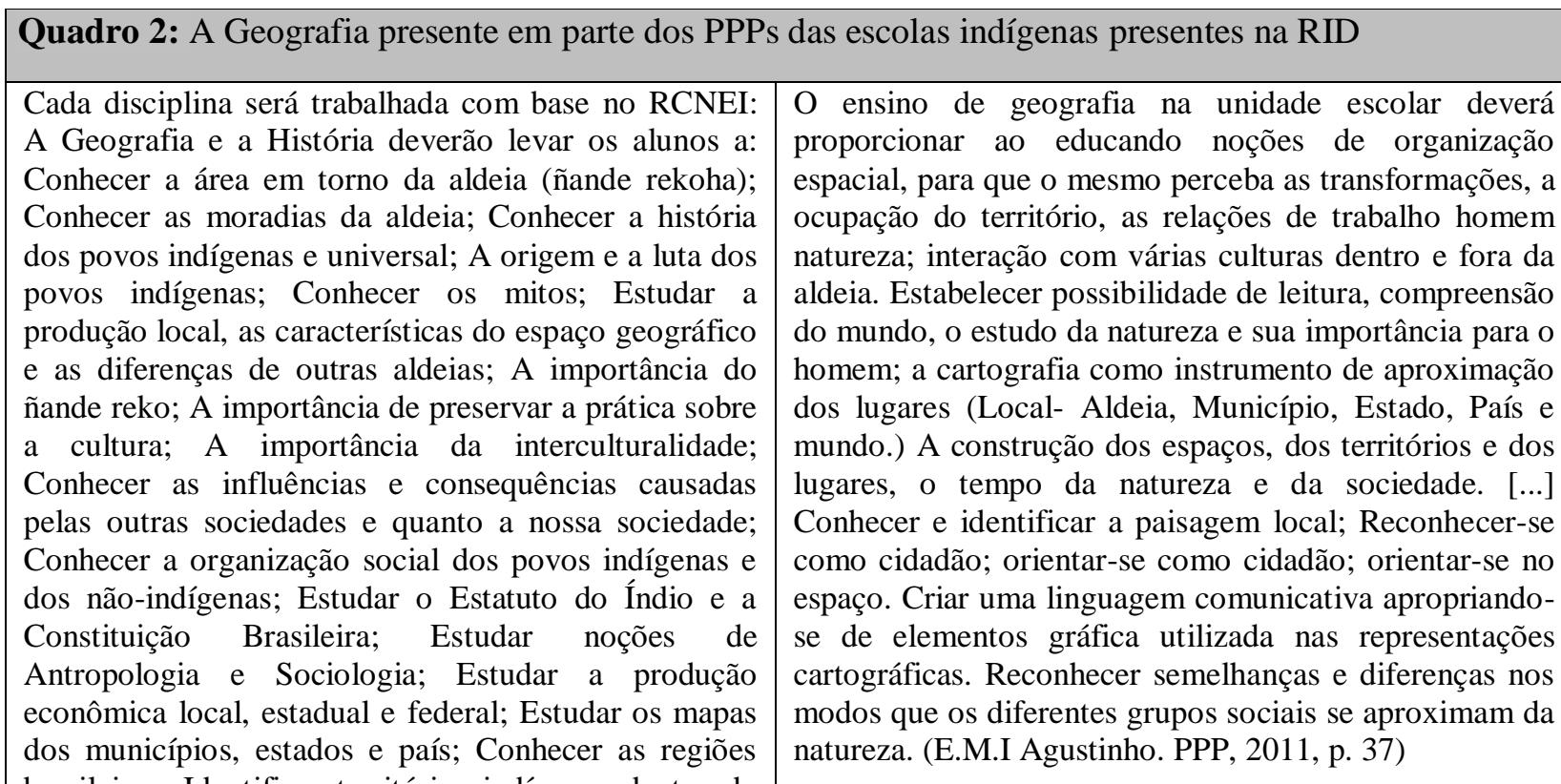
brasileiras; Identificar territórios indígenas dentro do Estado e do País; Estudar os direitos dos povos indígenas; (E.M.I. Araporã, 2015, p. 22)

O currículo de geografia nas escolas indígenas é de fundamental importância, pois tem a finalidade de refletir sobre as crenças sobre a origem do mundo, do homem, do sol, da lua, das matas e florestas, vindo também a associar os mitos indígenas de outras culturas e a sua relação entre o ser humano e a natureza. Os alunos precisam ter oportunidade de aprender inicialmente a orientar e localizar-se no espaço em que vivem, produzir e saber representá-lo, estudar mapas do local e outros diferentes tipos (RCNEI). [...] Em outras palavras o aluno vai estudar a geografia local, nacional e a internacional e voltará para geografia local. Estudando assim, o aluno entenderá que vivemos em uma sociedade globalizada num mesmo planeta. (E.M.I. Tengatui. PPP, 2010, p.50-51)

Org.: Silva, S.R. 2017

Cabe destacar, contudo, como identificado no PPP da Escola Municipal Indígena Tengatuí (quadro 2), que é imprescindível que ao considerarmos como referência o lugar de vivência do aluno, devemos ir do local para o global, retornando sempre ao local, possibilitando ao aluno atribuir significado aos conteúdos geográficos, numa relação dialética entre os conhecimentos trabalhados em sala de aula, e a realidade vivenciada em seu cotidiano. "Essa formulação está orientada pela compreensão dialética, que pressupõe a 
realidade na sua multiescalaridade e a totalidade dos fenômenos como resultante da relação contraditória entre o todo e a parte”. (CAVALCANTI, 2012, p.146)

A construção dos raciocínios espaciais complexos requer uma articulação dialética entre as diferentes escalas e configurações, ou como sinaliza Cavalcanti (2012), a multiescalaridade no tratamento dos fenômenos.

O global, conjunto articulado de processos, relações e estruturas do espaço, tem um significado específico e peculiar em cada lugar; mas esse lugar não pode ser apreendido completamente sem a tensão com a totalidade da qual faz parte. [...] Então, recomenda-se trabalhar respeitando o nível de abstração e de cognição das crianças ou dos jovens, sem dar definições formais de local ou de global, mas apontando evidências de um lugar como localização de algo, e também como experiência cotidiana, familiar, identitária, mas ainda como diferenciações, comparações, processos, relações de uma realidade objetiva e global. (CAVALCANTI, 2012, p. 166-167)

Nesse sentido, a Geografia se coloca como importante disciplina capaz de contribuir para a construção de uma escola indígena específica e diferenciada, uma vez que, a construção desta escola requer, fundamentalmente, que as análises realizadas tenham como ponto de partida os conhecimentos da comunidade em que a escola está inserida, retornando sempre a esses conhecimentos. Para tal, é necessário que cada currículo seja construído em consonância com os valores e interesses étnicos e políticos daquela comunidade, em relação aos seus projetos de sociedade e de escola.

No entanto, identificamos em parte dos objetivos propostos para o ensino de Geografia no interior dos PPPs das escolas indígenas pesquisadas (quadro 2), uma "abordagem conhecida como círculos concêntricos, que vai do local ao global, do mais imediato do aluno ao mais distante", herança de uma abordagem praticada tradicionalmente no anos iniciais do Ensino Fundamental em que os estudos se iniciavam pelo o espaço do aluno, passando para outras escalas (escola, bairro, município) de maneira linear, desconsiderando que a produção dos espaços de vivência dos alunos "é resultado de um processo histórico e social mais amplo, do qual esses espaços fazem parte." (CAVALCANTI, 2012, p.167)

Esta situação/condição também está presente na fala de um dos professores de Geografia atuante nas escolas indígenas do município de Amambai ${ }^{12}$, quando questionados sobre a contribuição da Geografia para Educação Intercultural, como podemos verificar a seguir:

\footnotetext{
${ }^{12}$ Não há nos PPPs das escolas indígenas do município de Amambai uma discussão específica acerca do objetivo e/ou importância da Geografia trabalhada nas escolas indígenas. 
A Geografia contribui sim. A interculturalidade do aluno. Porque através da Geografia, conhecendo o local, lugar, Estado, País. A realidade e a diferença cultural que existem no mundo. (Professor de Geografia da E.M.I Tupã'I Nandeva. Em entrevista pessoal, no ano de 2015)

Em partes contribui sim, mas poderia ter mais políticas voltadas para esta questão intercultural. (Professor de Geografia da E.M.I Mbo ' Eroy Guarani Kaiowá. Em entrevista pessoal, no ano de 2015)

A partir do momento em que é lançado um desafio ao aluno em descobrir o que está sua volta, a Geografia contribui com a educação intercultural, pois o aluno trabalha com as transformações do espaço, levando a criticidade, pesquisando, observando o espaço. (Professor de Geografia das E.M.I Mbo' Eroy Guarani Kaiowá e E.E I Mbo’ Eroy Guarani Kaiowá. Em entrevista pessoal, no ano de 2015)

Para não cair no risco de análises simplistas e reducionistas que acabam por justificar e/ou naturalizar problemas de ordem essencialmente social e/ou decorrentes de situações sociais, é necessário transitar nos vários níveis de escalas de análises, uma vez que um estudo de lugar em que não se considere as outras dimensões escalares existentes, recairá certamente, em análises simplistas, com explicações inadequadas aos fenômenos estudados (CALLAI, 2014).

Essa situação está evidenciada nos PPPs das duas escolas indígenas do município de Amambai (E.M.I Tupã I Ñandeva e E.M.I Mbo`Eroy Guarani e Kaiowá) que mesmo não apresentando uma discussão específica quanto ao objetivo e/ou importância da Geografia trabalhada nas escolas indígenas, trazem uma Organização Curricular em que os conteúdos propostos para a disciplina de Geografia, apesar de possuírem importantes significados para os Guarani e Kaiowá, não apresentam (no PPP) nenhum elemento que sinalize para a necessidade do diálogo entre os saberes indígenas e os conteúdos propostos para esta disciplina.

$6^{\circ}$ ANO - $1^{\circ}$ BIMESTRE - CONTEÚdOS INTRODUÇÃO À GEOGRAFIA: História da Geografia Orientação: pontos cardeais, colaterais e formas diversas de localização; Coordenadas geográficas: linhas imaginárias e Hemisférios terrestres; Movimentos da Terra: Translação e Rotação; Fusos horários; Cartografia: elementos de um mapa e tipos de mapas e escala geográfica; Espaço Natural e Geográfico; O UNIVERSO: Origem; Sistema Solar; Os Planetas; O Planeta Terra e sua evolução geológica (Deriva continental e Tectônica de placas).

HABILIDADES/COMPETÊNCIAS: Conceituar a Geografia considerando seu contexto histórico; Reconhecer e/ou empregar linguagem científica (símbolos e representações) relativa à Terra e ao sistema solar; Analisar argumentos que refutam ou aceitam conclusões apresentadas sobre características do Planeta Terra. (E.M.P. I T.Ñ. PPP, 2013, p.180) 
Como podemos verificar, mesmo com conteúdos que possibilitam o diálogo entre as diferentes racionalidades existentes, como localização e orientação, o desenvolvimento das competências e habilidades a serem desenvolvidas pelos alunos não consideram as possibilidades de diálogos com os saberes indígenas. A importância da localização para os Guarani e Kaiowá, que historicamente, utilizavam-na como forma de sobrevivência é destacada por Aquino (2012, p.28):

Os Guarani/Kaiowá costumavam se agrupar em áreas de matas e beira de rios, tendo em vista que isso facilitava a alimentação, como a caça e pesca para sustentar suas famílias. Era dessa forma que retiravam seus sustentos como meios de sobrevivência, sempre guiados por Deus "paikuara". Os Kaiowá gostavam de acampar ao longo dos córregos em pequenos grupos integrados por uma família ou mais, com quem mantinham fortes relações de parentesco, tendo como chefe sempre os mais velhos, por ter anos de experiências da vida, o "tekoharuvicha" (grande líderes) ou o "ñanderu" líder religioso, que estão a serviços dos deuses e que vão ensinar o melhor jeito de viver, tanto na sociedade quanto na vida espiritual, caminhando com o povo em busca da Terra Sem Males.

Todos os elementos destacados pela referida autora como importantes para a reprodução do modo de ser e viver Guarani e Kaiowá (matos, rios) permitem relação com os conteúdos a ser trabalhado na disciplina de Geografia (hidrografia, clima, vegetação) como podemos verificar a seguir. Porém, apesar das competências e habilidades apresentarem a necessidade de reconhecimento de que os fenômenos naturais têm influência no cotidiano da população, não apontam para a importância que a localização desses elementos possui para a luta diária destes povos, seja os que resistem em situação de reserva, nas periferias da cidade, nos acampamentos de retomada, ou em parte dos seus territórios tradicionais demarcados.

$6^{\circ}$ ANO 3- BIMESTRE - CONTEÚDOS HIDROSFERA: As águas continentais (rios, lagos); Hidrografia do Brasil; Águas subterrâneas; O relevo submarino; Oceanos e Mares; Hidrografia de Mato Grosso do Sul.

HABILIDADES/COMPETÊNCIAS: Compreender a importância da água para o mundo. Reconhecer a importância econômica das águas dos oceanos e mares. Localizar as principais bacias hidrográficas do Brasil com seus respectivos rios. Reconhecer a importância das águas subterrâneas. (E.M.P.I T.N. PPP, 2013, p.181)

$6^{\circ}$ ANO - $4^{\circ}$ BIMESTRE - CONTEÚDOS ATMOSFERA (CLIMA E VEGETAÇÃO): Fenômenos atmosféricos; O tempo e o clima; Formações vegetais; Relações entre clima e vegetação; Massas de ar Estações do ano; Climatologia de Mato Grosso do Sul

HABILIDADES/COMPETÊNCIAS: Reconhecer que os fenômenos naturais têm influência no cotidiano da população. Relacionar os climas às formações vegetais. Localizar os principais tipos climáticos, caracterizandoos. Compreender as alterações climáticas que ocorrem devido aos fenômenos naturais ou criadas. (E.M.P. I T.Ñ. PPP, 2013, p.180) 
Hidrografia, clima vegetação e relevo são elementos importantes para os Guarani e Kaiowá ocuparem seu território próximo aos rios, às matas, com solos férteis para plantar, propícios para sua sobrevivência. "Os Kaiowá e Guarani são mais conhecidos, na etnologia, como povos da mata, pois preferiam para a construção de suas aldeias, locais próximos, as regiões de mata, ou matas ciliares". (URQUIZA; BANDUCCI JR, 2013, p.183).

Os limites apresentados pelos conteúdos propostos no PPP da escola que desconsidera a importância histórica da localização para a sobrevivência dos Guarani e Kaiowá, reafirma a necessidade de articular cada um dos conteúdos propostos no PPP, diretamente relacionado ou não a vivência indígena, visando à construção de relações interculturais, de interação entre as etnias que vivem, por exemplo, no espaço reserva, assim com a população não indígena que vive em seu entorno, relações estas marcadas por situações de conflitos, de negação e exclusão.

Esta não é uma tarefa fácil de efetivar, uma vez que, a disciplina de Geografia, assim como as demais disciplinas que compõem o currículo escolar se insere numa racionalidade científico/formal que visa estabelecer uma "ordem", disciplinando e/ou controlando os diversos saberes existentes, por meio de um pacote organizado de conhecimentos, capturado por uma estrutura lógica, permeada por um saber científico superior, que desconsidera a produção e aceitação de qualquer outro tipo de conhecimento, obstáculo ao necessário controle da "natureza", visto como único meio de garantir o tão sonhado "progresso". "Esta é a visão de mundo que fornece os pressupostos fundacionais de todo o edifício dos conhecimentos sociais modernos". (LANDER, 2005, P.13)

Há que se considerar, assim, as ambiguidades presentes no contexto escolar que envolve, sobretudo, a prática pedagógica trabalhada em sala de aula e, consequentemente, a necessidade de descolonização do saber, que permanece arraigada em grande parte da nossa sociedade e se reflete nas práticas de parte dos professores em sala de aula, inclusive dos educadores (indígenas e não indígenas) atuantes nas escolas pesquisadas. Esta questão está evidenciada em parte das falas dos professores entrevistados (atuantes nas escolas indígenas dos três municípios pesquisados), quando questionados sobre seu entendimento acerca da educação intercultural. (Ver quadro 3) 


\begin{tabular}{|c|c|}
\hline \multicolumn{2}{|c|}{ Quadro 3: Entendimento dos professores de geografia entrevistados sobre a educação intercultural } \\
\hline $\begin{array}{l}\text { Educação intercultural é aquela que a escola } \\
\text { reconhece e mantém a diversidade cultural e } \\
\text { linguistica. A escola trabalha a perspectiva } \\
\text { intercultural, pois ensina o português, o guarani e } \\
\text { terena. (Professor de Geografia da E. M. I. Tengatuí e } \\
\text { E.E.E.M.I Guateka. Em entrevista pessoal no ano de } \\
\text { 2015.) }\end{array}$ & $\begin{array}{l}\text { A educação intercultural é saber trabalhar com as } \\
\text { diferenças. A escola respeita a especificidade da } \\
\text { formação das identidades culturais, por seu uma } \\
\text { escola indígena, promove sempre a articulação } \\
\text { entre os diferentes contextos. (Professor de } \\
\text { Geografia da E.M.I Mbo`Eroy Guarani Kaiowá e } \\
\text { E.E.I Mbo`Eroy Guarani Kaiowá. Em entrevista } \\
\text { pessoal no ano de 2015.) }\end{array}$ \\
\hline $\begin{array}{l}\text { Educação intercultural é uma educação onde } \\
\text { diferentes culturas possam dialogar. Culturas } \\
\text { diferentes podem conversar entre si. Sim, existe uma } \\
\text { tentativa de aproximação através das práticas em sala } \\
\text { de aula, cujo conteúdo suscita novas estratégias e } \\
\text { metodologia adequada na busca de construção das } \\
\text { identidades do individuo e o reconhecimento das } \\
\text { diferenças. Mas, ainda nos deparamos com inúmeras } \\
\text { dificuldades, nem mesmo o ambiente escolar } \\
\text { corresponde ao que se propõe. (Professora da de } \\
\text { Geografia da E. M. I. Ramão Martins. Em entrevista } \\
\text { pessoal no ano de 2015.) }\end{array}$ & $\begin{array}{l}\text { Educação intercultural é uma construção de ensino } \\
\text { diferente, de identidade própria, ou seja, a } \\
\text { valorização de uma determinada cultura, sem } \\
\text { desconsiderar a outra. É um "desenvolvimento" } \\
\text { (entendimento) diferente de sociedade. Tendo em } \\
\text { maior perspectiva, a valorização da cultura, da } \\
\text { língua guarani, reza das tradições, até mesmo, da } \\
\text { união da família, e para o desenvolvimento do } \\
\text { Guarani e Kaiowá. (Professor de Geografia da } \\
\text { Escola Estadual Yvy Poty. Em entrevista pessoal } \\
\text { no dia 06/10/2015 }\end{array}$ \\
\hline $\begin{array}{l}\text { Olha, a escola trabalha a educação intercultural. } \\
\text { Porque no início do ano nós tivemos alguns trabalhos } \\
\text { sobre a cultura indígena, então a língua, as comidas } \\
\text { típicas, tudo isso a gente teve que trabalhar aqui no } \\
\text { começo do ano. Isso pra mim é intercultural. Porque } \\
\text { têm as três etnias, mas a gente não pode ficar preso } \\
\text { nisso, a gente tem que atender a todos de uma forma } \\
\text { geral, mas respeitando a cultura de cada um. } \\
\text { (Professora da de Geografia da E. M. I. Agustinho. } \\
\text { Em entrevista pessoal no ano de 2015.) }\end{array}$ & $\begin{array}{l}\text { Acredito que sejam as práticas educacionais que } \\
\text { abranjam seus conhecimentos e tradições, sua } \\
\text { cultura e seu saber, na qual desenvolva atividades } \\
\text { voltadas a proporcionar o resgate da tradição dos } \\
\text { povos Guarani/Kaiowá. Dentro dessa perspectiva a } \\
\text { nossa escola é bem dinâmica. As práticas } \\
\text { interculturais ocorrem frequentemente com } \\
\text { atividades desenvolvidas em projetos. (Professor } \\
\text { de Geografia da Escola EstadualYvy Poty. Em } \\
\text { entrevista pessoal no dia } 06 / 10 / 2015 \text { ) }\end{array}$ \\
\hline $\begin{array}{l}\text { Intercultural é a escola trabalhar as duas realidades, } \\
\text { tanto português, e ao mesmo tempo Guarani. Isso eu } \\
\text { entendi que é intercultural. A Geografia contribui sim } \\
\text { para trabalhar a interculturalidade dos alunos, porque } \\
\text { através da Geografia ele conhece o local, lugar, país, } \\
\text { estado, a realidade e as diferenças culturais que } \\
\text { existem no mundo. (Professor de Geografia da E.M.I } \\
\text { Mbo`Eroy Tupã I N Nandeva. Em entrevista pessoal no } \\
\text { ano de 2015.) }\end{array}$ & $\begin{array}{l}\text { A concepção intercultural é você ter os dois } \\
\text { contatos, é você conhecer e valorizar outras } \\
\text { culturas, e intermediar, fazer dialogar todas as } \\
\text { ciências. (Professor de Geografia da Escola } \\
\text { Municipal Indígena Nandejara Polo. Em entrevista } \\
\text { concedida a Danielii Manfré no dia } 20 \text { de maio de } \\
2015 \text {. }\end{array}$ \\
\hline
\end{tabular}

Org.: Silva, S.R. 2017

As falas dos professores de Geografia presentes no quadro 3, demonstram que há consenso quanto ao reconhecimento e respeito à diversidade linguística e cultural de cada comunidade. Comparece nas falas dos professores das escolas dos três municípios pesquisados a necessidade de diálogo entre os saberes. Entendemos que a ênfase conferida à afirmação da identidade, assim como a importância atribuída aos diálogos entre os diferentes saberes, são elementos indispensáveis para a construção de uma educação intercultural, uma vez que como enfatiza Castrogiovani (2014, p.13):

[...] a construção da identidade é, na verdade, a representação das diferenças do sujeito; são suas marcas/sinais e a valorização de tais singularidades. Em outras palavras, a construção da identidade é a tomada de consciência de que 
eu sou diferente e por ser diferente é que existo e possuo valor social. O homogêneo não existe. São as diferenças que possibilitam os diálogos e as trocas, assim, o constante crescimento social do sujeito.

No entanto, a fala dos professores não aponta para um questionamento acerca das relações assimétricas existentes entre os (des)encontros entre os Guarani e Kaiowá e a “chamada" sociedade nacional.

Em sua maioria, os (as) professores (as) entrevistados (as), não evidenciam as relações de poder existentes entre os contatos culturais, demonstrando a tensão constante entre o fazer diferente e a herança colonial ainda presente nos contextos das escolas indígenas. Assim, apesar de propor o diálogo entre os saberes indígenas e os conhecimentos não indígenas, a concepção de grande parte dos professores se aproxima da interculturalidade funcional/neoliberal, proposta pelo professor Fidel Tubino, que "busca promover el diálogo sin tocar las causas de la asimetría cultural” (2004, p.6)

Concordamos com Walsh (2010) que esse discurso acaba por esvaziar e inviabilizar o real sentido da interculturalidade, tornando-a funcional ao sistema de mundo moderno, colonial. "Busca promover el diálogo, la convivencia y la tolerancia, sin tocar las causas de la asimetría y desigualdad social y cultural, y sin “cuestionar las reglas del juego". (p.7)

[...] reconoce la diferencia, sustentando su producción y administración dentro del orden nacional, neutralizándola y vaciándola de su significado efectivo, y volviéndola funcional a este orden y, a la vez, a los dictámenes del sistema-mundo-moderno-colonial. (WALSH, 2010, p.7)

Apesar de todos os limites e desafios constatados, identificamos na fala da professora atuante na Escola Municipal Indígena Araporã ${ }^{13}$ localizada na Reserva Indígena de Dourados $^{14}$, elementos que nos remetem a educação intercultural crítica proposta por Fidel Tubino, em que a análise sobre os encontros e (des) encontros entre os diferentes saberes e práticas, considere as relações de poder existentes entre as três etnias, assim como sua relação com os não índios (karaí) que vivem no entorno ou até mesmo dentro da Reserva.

Intercultural é quando você aborda assuntos, da sociedade não indígena, relacionando com os assuntos próprios da cultura indígena. Quando você

\footnotetext{
${ }^{13}$ A professora Alice Rosane Benites possui graduação em Geografia pela Universidade Federal de Mato Grosso do Sul 1988. Atuou como professora de Geografia na escola municipal indígena Araporã até o ano de 2015, momento em que iniciamos nosso trabalho de campo. A partir do ano de 2016 passou a ministrar aulas na escola municipal Agustinho, ambas localizadas na aldeia Bororó.

14 Durante trabalho de campo realizado nos anos de 2015 e 2016 identificamos uma série de atividades desenvolvidas pela professora em questão (desenhos, teatro, danças, musicas, filmes) que se aproximam da perspectiva de educação intercultural que defendemos, pois promove o diálogo entre os diferentes grupos sociais e culturais, considerando os conflitos resultantes das relações de poder existentes, favorecendo, assim, a construção de um projeto comum no qual as diferenças sejam dialeticamente integradas. (CANDAU, 2013).
} 
possibilita ao aluno a afirmação dos conhecimentos indígenas, mas também possibilite o acesso a outros saberes. Aqui na Reserva mesmo nós temos três etnias, então, tem que considerar as três etnias. E não podemos esquecer que os indígenas principalmente aqui de Dourados, não vivem isolados, eles estão convivendo a todo o momento, com não indígenas, inclusive aqui na escola. Então esses alunos tem o direito de ter acesso a esse conhecimento não indígena. Agora a maneira como você vai fazer isso é que é importante. Por exemplo, quando eu trabalho a questão da criação da Reserva, porque antes o índio era livre não existiam fronteiras, ele não tinha limites, podia andar por onde queria, ele não precisava do outro para sobreviver. E a partir da chegada do não índio eles perderam parte de suas terras, e essa barreira foi criada, e, esse limite foi imposto. (Professora da de Geografia da E. M. I. Araporã. Em entrevista pessoal no ano de 2015.)

Há, em sua fala, uma preocupação voltada para a afirmação da identidade Guarani e Kaiowá e Terena, reconhecimento da valorização aos saberes e conhecimentos indígenas. $\mathrm{O}$ direito dos alunos ao acesso aos conhecimentos "outros", inclusive dos não índios, devido ao contato constante com os karaí, também está presente em sua reflexão. Porém, a professora avança principalmente quando chama atenção para a forma como a qual o professor vai intermediar o diálogo entre os diferentes saberes, uma vez que essa não foi e não é uma relação de troca recíproca.

Os elementos destacados pela professora comparecem em atividades elaboradas ${ }^{15}$ por alunos indígenas nas aulas de Geografia. $\mathrm{Na}$ figura 2 podemos verificar o contexto multiétnico que permeia a composição RID, em que vivem em um mesmo espaço três diferentes etnias e apesar dos Kaiowá e Guarani possuírem historicamente características muito semelhantes, existem particularidades que devem ser consideradas ${ }^{16}$. E, é necessário considerar ainda, a presença de uma terceira etnia: os Terena.

\footnotetext{
15 Dentre estas atividades identificamos e analisamos desenhos e textos complementares, escritos em Língua Portuguesa e traduzidos para o Guarani, os quais de acordo com a professora Alice, são utilizados em suas aulas como complemento ao livro didático.

${ }^{16}$ Apesar não haver consenso sobre quais seriam as principais características de cada subgrupo, Pereira (1999) organizou um quadro em que destaca algumas características próprias de cada subgrupo, em especial no que diz respeito a religião, cerimônias religiosas e relação com espaço territorial.

Silva e Nunes, $2019 \quad$ ISSN 0104-5490 


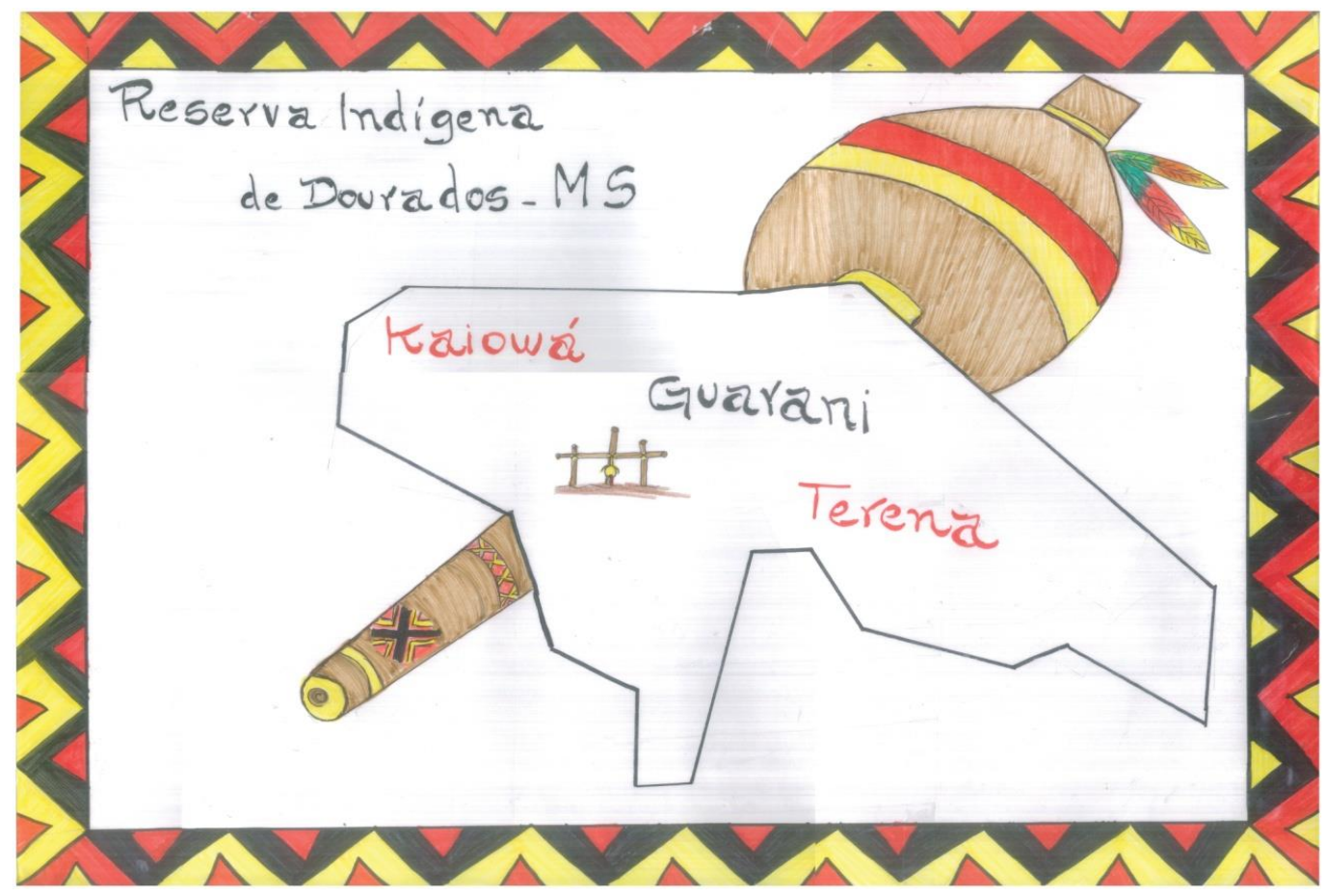

Figura 02: Mapa das etnias existentes no interior da RID

Autoria: Trabalho elaborado pelos alunos da Escola Araporã, sob orientação da professora Alice Fonte: Trabalho de Campo, 2015.

Além do contexto multiétnico, chama atenção às ressignificações simbólicas atribuídas a cartografia do não índio, ao inserir elementos simbólicos do seu existir cotidiano (mbaraka, yvyra marangatu), subvertendo o sentido de representação. Símbolos/elementos que expressam outras cartografias possíveis.

Todas estas questões são fundamentais para compreensão sobre a realidade em que vivem os Guarani e Kaiowa, pois como salienta Brand (1997), o impacto da perda da terra não pode ser avaliado tendo em conta apenas número de aldeias destruídas, deslocadas, esparramadas, mas também, as consequências das alterações no modo de vida dos Guarani e Kaiowá.

Ao serem submetidos à situação de reserva nas áreas de acomodação resultante da sobreposição dos tekoha ${ }^{17}$, estas comunidades passaram a reunir comunidades que antes não interagiam em caráter permanente, causando uma série de problemas organizacionais, acrescentados pela presença de sujeitos sociais pertencentes à chamada sociedade nacional, o

\footnotetext{
${ }^{17}$ A transferência dos tekora para dentro das reservas demarcadas vai acarretar profundas transformações para a vida dos Guarani e Kaiowá, que tiveram seus espaços bruscamente reorganizados, não respeitando os padrões tradicionais existentes até aquele momento no interior de seus tekoha; profundas mudanças na economia, por meio da imposição do trabalho assalariado como forma de subsistência; alterações no sistema de chefias com o surgimento e fortalecimento da figura do capitão acarretando na expressiva deteriorização da saúde e aumento da violência interna. (BRAND, 1993)
} 
que constitui a área de acomodação como um cenário multiétnico de interação permanente. (PEREIRA, 2007)

Essa realidade também se faz presente no município de Caarapó onde identificamos uma atenção voltada para a afirmação e valorização dos saberes tradicionais, enquanto eixo central dos projetos educacionais, o que demonstra conquistas na luta pela descolonização do saber.

Na Escola Municipal Indígena Ñandejara Polo, no que se refere às séries iniciais do Ensino Fundamental, constatamos no PPP da escola, que a educação intercultural avança no sentido de promover o diálogo entre os saberes tradicionais e a base nacional comum numa relação dialética em que por meio um mesmo tema gerador, o educador dialoga com as diferentes áreas do saber.

Contudo, a partir do $6^{\circ}$ ano do Ensino Fundamental o conhecimento se encontra fragmentado nas diferentes áreas do saber. No entanto, Silva (2016) salienta que apesar dos planejamentos demonstrarem uma ênfase atribuída aos conteúdos universais, os professores têm buscado dialogar com a cultura e realidades destes povos.

Durante acompanhamento das aulas de Geografia na escola municipal indígena Nandejara Polo, Silva (2016) constatou que os professores atuantes na referida escola, ao trabalharem os conteúdos propostos com base em um planejamento e livro didático colonial/ocidental - buscam relacionar à visão cósmica que os Guarani e Kaiowá possuem sobre cada conteúdo proposto (figura 3 ).

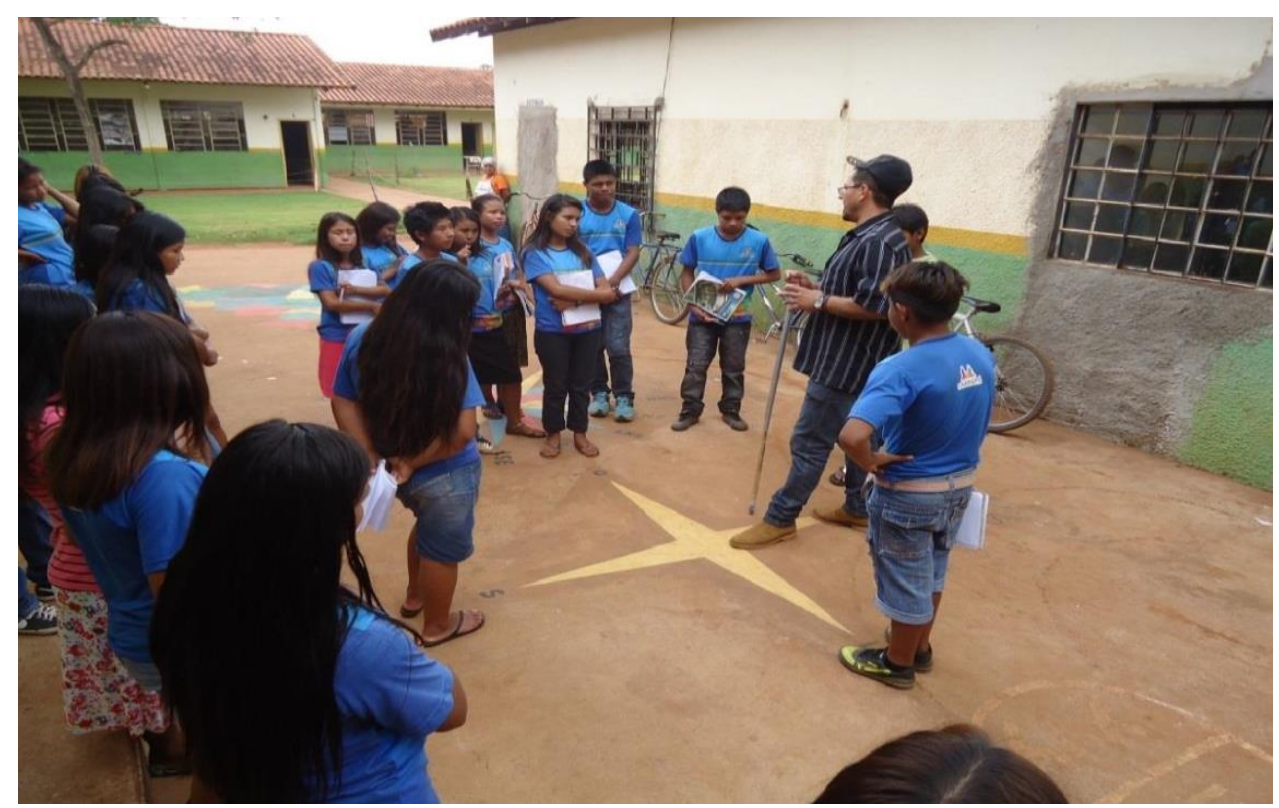

Figura 03: Atividades com os pontos cardeais

Fonte: Silva, D.M. (2015) 
$\mathrm{Na}$ atividade ilustrada na figura 03, o conteúdo proposto a ser trabalhado com os alunos do $6^{\circ}$ ano foi pontos cardeais. Mas para além da orientação determinada pelos pontos cardeais, presente no livro didático, o professor buscou atribuir ao conteúdo significado para a vida dos alunos, uma vez que, partindo da visão cósmica Guarani, “Os pontos cardeais enquanto forças que regem o mundo terreno indicam como os povos Guarani devem se orientar e localizar sua casa, sua roça e outros objetos de modo a manter uma sintonia com o lugar [...]”. (LIMA, 2012, p. 85)

É importante destacar que a metodologia trabalhada na escola é subsidiada a partir de temas geradores, e pautada nos princípios de que educar não é transferir conhecimento, mas criar possibilidades para sua construção. Assim, apesar do planejamento elaborado pelos professores apresentar maior ênfase nos conteúdos considerados "universais", a partir dos temas geradores busca-se ressignificar os conteúdos propondo o diálogo entre a Geografia institucionalizada ${ }^{18}$ com as várias geografias existentes no espaço reserva.

De maneira geral, apesar da complexidade que envolve o processo de desconstrução da escola colonial, identificamos que em ambas as escolas indígenas do município de Amambai, assim como nas escolas estaduais do município de Caarapó (E.E. Yvy Poty) e Dourados (E.E.E.M.I. Guateka) existe uma ênfase atribuída à proposta da interculturalidade por meio do desenvolvimento de projetos, nos quais, alguns temas são propostos e trabalhados de maneira interdisciplinar. Essas questões demonstram que para além dos limites impostos pela colonização do saber, é necessário pensarmos em práticas que rasurem o currículo institucional formal, criando possibilidades de (re) existência ao modelo educacional colonial existente.

\section{CONSIDERAÇÕES FINAIS}

Guardadas as particularidades presentes em cada realidade, identificamos que as concepções de interculturalidade presentes no cotidiano das escolas indígenas pesquisadas, evidenciam as dubiedades que permeiam a luta pela construção de uma educação intercultural/descolonial, uma vez que as falas dos professores entrevistados, assim como a análise aos PPPs das referidas escolas, demonstram as conquistas - em especial a partir da construção e reafirmação e fortalecimento de sua identidade, a partir, sobretudo, da

\footnotetext{
${ }^{18}$ Esta Geografia institucionalizada e também compreendida por alguns autores como Oliveira Jr. (2009) como Geografia Maior do Estado, escrita com letra maiúscula (Geografia), produzida na macropolítica, nos gabinetes, expressa nos documentos, nos grandes mapas e projetos construídos com base nas estruturas da linguagem científica referência de objetividade e verdade. 
valorização dos conhecimentos tradicionais - mas também os limites que esta disciplina vem enfrentando, em especial no que se refere à efetiva compreensão do que seria de fato uma educação intercultural.

Esta situação/condição resulta do fato de que apesar da inserção dos conhecimentos indígenas no currículo escolar, esses conhecimentos foram transformados em disciplinas, organizados na mesma lógica fragmentada que estrutura os conhecimentos não indígenas. Com base na análise de Walsh (2009), compreendemos que é necessário ultrapassarmos os debates enraizados no diálogo em torno da diversidade-etnicocultural e focalizar o problema na "ciência" em si, construída com base em um pensamento e conhecimento totalitário, únicos e universais. A ciência é um dos fundamentos centrais do projeto modernidade/colonialidade, fundamental não somente para o estabelecimento, mas para a “manutenção da história e atual ordem hierárquica racial, na qual os brancos, especialmente os homens brancos europeus, permanecem em cima”. (WALSH, 2009, p.24)

A reflexão realizada acerca da concepção de educação intercultural dos professores de Geografia entrevistados reafirma a complexidade presente nos contextos educacionais das escolas presentes nas reservas indígenas, marcadas pela tensão entre o fazer diferente e a colonialidade ainda presente em todas as esferas da sociedade, inclusive nos espaços educacionais, e consequentemente a necessidade de práticas pedagógicas que valorizem o diálogo entre os conhecimentos geográficos e os saberes e geografias outras.

\section{REFERÊNCIAS}

AQUINO. Elda Vasquez. Educação escolar indígena e os processos próprios de aprendizagens: espaços de inter-relação de conhecimentos na infância guarani/kaiowá, antes da escola, na comunidade indígena de Amambai, Amambai - MS. 2012. 118 p. Dissertação (Mestrado em Educação) - Universidade Católica Dom Bosco, Campo Grande-MS.

BENITES, ELIEL. Oguata pyahu (uma nova caminhada) no processo de desconstrução e construção da educação escolar indígena da reserva indígena te'ýikue. 2014. 165 p. Dissertação (Mestrado em Educação). Universidade Católica Dom Bosco, Campo GrandeMS.

BRAND, Antonio Jacó. O impacto da perda da terra sobre a tradição Kaiowa/Guarani: os difíceis caminhos da Palavra. 1997. 382 p. Tese (Doutorado em História) - Pontifícia Universidade Católica do Rio Grande do Sul, Porto Alegre.

CANDAU, Vera Maria. Multiculturalismo e educação: desafios para a prática pedagógica. IN: MOREIRA, Antonio Flávio. CANDAU, Vera Maria. Org. Multiculturalismo diferenças culturais e práticas pedagógicas. 10 ed. Petrópolis, Rio de Janeiro: Ed. Vozes, 2013, p.1337 
CAVALCANTI, Lana de Souza. O ensino de Geografia na escola. Campinas: Papirus, 2012.

. A Geografia e a realidade escolar contemporânea: avanços, caminhos, alternativas. Anais do I Seminário nacional: currículo em movimento - Perspectivas Atuais Belo Horizonte, novembro de 2010.

FERREIRA, Mariana Kawal Leal. A educação escolar indígena: um diagnóstico crítico da situação no Brasil. In: LOPES da SILVA, Aracy; FERREIRA, Mariana Kawal Leal (Orgs.). Antropologia, história e educação: a questão indígena e a escola. São Paulo: Global, 2001. p. 71-111.

LANDER, Edgardo. Ciências sociais, violência epistêmica e o problema da invenção do outro. IN: _ A colonialidade do saber: eurocentrismo e ciências sociais latinoamericanas. Buenos Aires: CLACSO, 2005, p.8-23

MATO GROSSO DO SUL. Relatório de dados populacionais do Sistema de Atenção a Saúde Indígena (SIASI). Disponível em: http://dw.saude.gov.br/ Acesso em: 30/05/2015.

Secretaria de Estado de Educação. Dados Oficiais do Censo Escolar de 2015. Disponível em: www.sed.ms.gov.br. Acesso em: 10/12/2016.

SANTOS, Douglas. O que é Geografia? São Paulo, 2007, apostilado.

SKLIAR, Carlos. Pedagogia (improvável) da diferença. E se o outro não estivesse aí? Rio de Janeiro: DP\&A, 2003. 224 p.

SILVA, Danielli Manfré da. O ensino de geografia na educação escolar indígena: reflexões com base na escola municipal indígena ñandejara poló em caarapó (MS). 2016. 122 p. Dissertação (Mestrado em Geografia) - FCH, UFGD, Dourados-MS.

SOUZA, Maria Izabel Porto de; FLEURI, Reinaldo Matias. Entre limites e limiares de culturas: educação na perspectiva intercultural. In: FLEURI, Reinaldo Matias (Org.). Educação intercultural: mediações necessárias. Rio de Janeiro: DP\&A, 2003. p. 5384.

TUBINO, Fidel. Del Interculturalismo funcional al interculturalismo crítico. 2004. Disponível em: www.pucp.edu.>. Acesso 01/10/2014

WALSH, C. Interculturalidade crítica e pedagogia decolonial: in-surgir, re-existir e re-viver. In: CANDAU, Vera. Org. Educação intercultural na América Latina: entre concepções, tensões e propostas. Rio de Janeiro: Ed 7 letras, 2009, p. 12-43.

Interculturalidad crítica y pluralismo jurídico. Ponencia presentada en el Seminario Pluralismo Jurídico, Procuradora del Estado/Ministerio de Justicia, Brasilia, 13-14 de abril 2010. 